\title{
DOWODY ISTNIENIA BOGA A FENOMEN RELIGII
}

Już w poprzednich naszych publikacjach ${ }^{1}$ poruszaliśmy częściowo zagadnienie stosunku pomiędzy religijnym poznaniem Boga a dowodami Jego istnienia. Chcąc ustalić tę relację wychodziliśmy dotychczas przede wszystkich $\mathrm{z}$ analizy religijnego poznania ${ }^{2} \mathrm{i}$ to zarówno od strony jego treści jak i samego aktu. Przy tym zwróciliśmy uwage na spontaniczny charakter poznania religijnego i refleksyjny poznania filozoficznego.

$\mathrm{Na}$ podstawie dotychczasowych analiz doszliśmy do odmiennego ujęcia aniżeli to mamy np. u Pascala, Schelera czy Guardiniego ${ }^{3}$. - Analizując dane doświadczenia religijnego mogliśmy $\mathrm{m}$. in. stwierdzić, że zawarty w nim mamy całościowy moment przedmiotu, w którym wyróżnić możemy również te momenty, które zdają się stanowić przedmiot dowodzenia rozumowego ${ }^{4}$. Biorąc zaś pod uwagę spontaniczny charakter poznania religijnego i refleksyjny poznania filozoficznego, scharakteryzowaliśmy dowody istnienia Boga jako refleksję krytyczną przeprowadzoną nad owym bezpośrednim ujęciem i próbą wykazania jego słuszności ${ }^{\mathbf{5}}$. Stąd zaś doszliśmy do konkluzji, że jakkolwiek obie czynności poznawcze odbywają się na różnych płaszczyznach, pierwsza jest bezpośrednią, spontaniczną czynnością poznawczą, a druga teoretyczną refleksją, to zasad-

1 Problem filozofii religii, „Studia Philosophiae Christianae”, 1967, s. 169-194. Religijne poznanie Boga wedtug Romano Guardiniego, Warszawa, 1967, ss. 154-159; Przedfilozoficzne i filozoficzne poznania Boga, w: Studia z filozofii Boga, Warszawa, 1968, Ss. 333-347; Bóg filozofów i Bóg wierzq̨cych, w: O Bogu i o człowieku, t. II, Warszawa, 1969. ss. 97-106.

2 Por. Religijne poznanie Boga wedtug Romano Guardiniego, ss. 145 ns.; 152 ns.

3 Por. Religijne poznanie Boga wedtug Romano Guardiniego, ss. 157-159; Bóg filozofów i Bóg wierzacych, ss. 105-106.

4 Por. Religijne poznanie Boga wedtug Romano Guardiniego, s. 153.

5 Por. Problem filozofii religii, ss. 190-192; Religijne poznanie Boga wedlug Romano Guardiniego, s. 156. 
niczo filozofia nie ,stwarza” nowego Boga, który różni się od Boga religii ${ }^{6}$.

Bóg filozofii, poznania rozumowego może być (u św. Augustyna i św. Tomasza faktycznie tak jest), choć nie w każdej filozofii tak jest - (Bóg Arystotelesa czy Bergsona, jak to $\mathrm{m}$. in. stwierdza Gilson, nie jest Bogiem religii chrześcijańskiej) ${ }^{7}$ tym samym Bogiem, który jest w religii, religia zaś ze swej strony nie musi być ,irracjonalna”, aby wykluczała od wewnątrz to, $\mathrm{z}$ czym spotykamy się $\mathrm{w}$ planie czysto teoretycznego poznania. Przeprowadzone refleksje nad różnymi formami doświadczenia religijnego miały być próbą wykazania, że tego rodzaju ujęcie w oparciu o różne stany rzeczy jest możliwe ${ }^{8}$.

Stosunkiem pomiędzy spontanicznym poznaniem Boga a filozoficznym poznaniem zajmowaliśmy się osobno ${ }^{9}$, nawiązując do poglądów lowańskiego profesora Alberta Dondeyna. Doszliśmy w tym artykule do podobnych wniosków jak w poprzednich pracach, a mianowicie, że tzw. „dowody istnienia Boga" są w określonym sensie krytyczną analizą tego, co uprzednio dokonało się $\mathrm{w}$ spontanicznym procesie poznania ${ }^{10}$.

Równocześnie zaznaczyliśmy już parokrotnie, że należy dokonać bliższej analizy dowodów istnienia Boga, aby wykazać, że to, co się w nich zawiera, wyraża na sposób filozoficzny pierwotny proces duchowy o charakterze religijnym.

W niniejszym artykule chcemy podjąc się tego zadania biorąc za punkt wyjścia poglądy Bernharda Welte zawarte przede wszystkim, choć nie wyłącznie, w jego rozprawie Der Gottesbeweis und die Phänomenlogie der Religion ${ }^{11}$ i konfrontując je z poglądami takich myślicieli jak: Gilson, Maritaina częściowo także i Heidegger. Wybór tych myślicieli nie jest przypadkowy. Welte nawiązując do św. Tomasza w pewien sposób stara

6 Por. przede wszystkim: Bóg filozofów i Bóg wierzacych, ss. 101-103. Por. również M. Nédoncelle, Teologia a filozofia, czyli o metamorfozach stużebnicy, "Concilium", 1-10 (1965/6), ss. 454. - Oczywistą jest rzeczą, że wyrażając taki pogląd nie sprowadzamy ani filozofii do religii ani religii do filozofii. Stanowisko nasze pokrywa się całkowicie z tym, które zajmuje Claude J. Geffré w swej rozprawie: Teologia naturalna $i$ Objawienie $w$ poznaniu Boga jedynego, w: Studia $z$ filozofii Boga, ss. 252-281.

7 Por. E. Gilson, Le Philosophe et la Théologie. Tłum. polskie: Filozof i Teologia, Warszawa, 1968, ss. 130 ns.

8 Por. szczególnie: Religijne poznanie Boga wedtug Romano Guardiniego, ss. $144-146 ; 152-154 ; 156-158$.

9 Przedfilozoficzne i filozoficzne poznanie Boga, por. przypis 1.

10 Przedfilozoficzne $i$ filozoficzne poznanie Boga, ss. 345-346.

11 Zamieszczone w: Auf der Spur des Ewigen. Philosophische Abhandlungen über verschiedene Gegenstände der Religion und der Theologie, Freiburg-Basel-Wien, 1965, ss. 315-337. - Dla lepszego i pełniejszego zrozumienia poruszanego problemu, jak i stanowiska Weltego uwzględnione zostaną ponadto zawarte w tymże zbiorze następujące rozprawy: Zum Seinsbegriff des Thomas von Aquin, ss. 185197; Die Gottesfrage im Denken Heideggers, ss. 262-278; jak również artykuł zamieszczony w polskim "Concilium', 1-10 (1966), p.t. Filozoficzne poznanie Boga a możliwość ateizmu, ss. 468-476. 
się przerzucać most pomiędzy tomizmem a myślą Heideggera (por. rozprawy w Auf der Spur des Ewigen). Zaś Gilson porusza to zagadnienie konfrontując je ze stanowiskiem Heideggera. ${ }^{12}$ Zdaje się zachodzić ponadto różnica stanowisk pomiędzy Weltem a Gilsonem w interpretacji kresu dróg filozoficznego poznania Boga. Poglądy zaś Maritaina zawarte przede wszystkim w Approches de Dieu są ważne dla nas ze względu na przedstawioną tam naturalną, spontaniczną drogẹ poznania Boga i stosunku do niej pięciu dróg św. Tomasza. Pod koniec dokonamy podsumowania wyników, do których doszliśmy. Czynimy to w tym zamiarze, aby wyjaśnić bliżej swoje własne stanowisko zawarte $\mathrm{w}$ poprzednich publikacjach, jak również, by usunąć pewne nieporozumienia narastające co do zadań filozofii religii, a zwłaszcza stosunku pomiędzy religijnym poznaniem Boga a filozoficznym dowodzeniem jego istnienia.

\section{POSTULAT HUSSERLA FILOZOFICZNEGO WYJASNIENIA NAUK A BADANIA NAD RELIGIA}

W interesującym nas zagadnieniu: dowody istnienia Boga a fenomenologia religii, B. Welte wychodzi z postulatu E. Husserla, domagającego się filozoficznego wyjaśnienia wszystkich nauk. Zdaniem jego wszystkie nauki budują się na pewnych ideach i podstawowych pojęciach, które wewnątrz nich samych nie mogą się stać tematem badań. Należy zatem wyjaśnić co właściwie oznaczają owe podstawowe pojęcia i z czego początkowo wyrasta ich znaczenie. W języku Husserla można to oddać następująco: należy ująć noematyczną zawartość podstawowych pojęć i to ze względu na ukazującą się $\mathrm{w}$ nich istotę jak i ze względu na ich pochodzenie. Tego rodzaju wyjaśnienie podstawowej noematycznej zawartości nie ma nic wspólnego ze spekulacją dotyczącą istoty, którą przeprowadza się z zewnątrz. Zasadnicze wyjaśnienie może się dokonywać tylko $\mathrm{w}$ ten sposób, że podstawowe eidetyczne treści będą poszukiwane w swojej pierwotności, z niej będą zaczerpnięte tak, że nic do tej pierwotnej treści (zawartości) nie będzie dodane.

Musimy już wiedzieć, co myślimy mówiąc np.: natura, historia, zanim będziemy mogli iść w kierunku dalszego wyjaśnienia. Chodzi właśnie o wyjaśnienie tego początkowo pomyślanego $\mathrm{z}$ niego samego albo z jego pierwotnie danych. Oznacza to zarazem powrót do tych początków i podstaw, z których wyrastają podstawowe określenia nauk.

Metodyczny postulat dotyczący wszelkiej nauki — zdaniem B. Welte jest bezsporny, niezależnie od tego, czy on sam zawsze był mu wierny i czy jego umieszczenie $\mathrm{w}$ nawiasie zagadnienia istnienia było słuszne

12 Por. Byt $i$ Bóg, w: Studia z filozofii Boga, ss. 281-332; równ.: Byt i istota, Warszawa, 1963, ss. 319 ns. 
i mimo to, że wiele elementów modyfikujących od tego czasu do jego podstawowej myśli zostało dokonanych ${ }^{13}$.

W związku z tym B. Welte uważa, że należy postawić pytanie, czy postulat wyjaśnienia noematycznych, eidetycznych podstaw i początków musi być postawiony także odnośnie wiedzy o religii w ogólności, a szczególnie w odniesieniu do chrześcijańskiej teologii. W rzeczywistości, ciągnie on dalej, jest oczywiste, że w nauce o religii w ogólności i w objawionej w szczególności należy zapytać skąd pochodzą pierwotnie ją konstytuujące treści znaczeniowe, jak ukazują się one w początkowo danych aktach i jakie to są akty. Należy więc najpierw zapytać co mniemamy mówiąc „Swięty”, „Bóg”, lub gdy używamy podobnych im wyrazów. Jaką miarą posługujemy się gdy rzeczywiste lub pomyślane przedmioty mierzymy tego rodzaju noematami? Dlaczego nazywamy Boga Bogiem i Świętego Świętym? I czy można dla tego rodzaju noematów wyznaczyć pierwotne rejony i gdzie one się znajdują? Pytanie to jest znowu podwójne: pyta ono o sposób tego, co się na początku ukazuje i o sposób początkowego ujmowania tego, co się ukazuje. Są to podstawowe pytania dla ukonstytuowania teologii jako nauki.

Rodząca się stąd problematyka wymaga rozwinięcia w wielu kierunkach. B. Welte $z$ jej zasięgu wybiera dowody istnienia Boga. W odniesieniu do nich rozpatruje w zarysie wymienione wyżej pytania.

\section{DOWODY ISTNIENIA BOGA A DZIEDZINA RELIGII}

a) Stanowisko B. Welte.

W dowodzeniu istnienia Boga - zdaniem Weltego - ma miejsce teoretycznie artykułowane, filozoficzne wykazanie istnienia Boga i przez to samo fundamentu dziedziny świętości i religii w ogóle ${ }^{14}$. Swoją klasyczną formę dla teologii otrzymały dowody istnienia Boga u św. Tomasza. Oczywiście, nie twierdzi się przez to, że dziedzina świętości faktycznie dopiero przez dowody istnienia Boga $w$ ich teoretycznej, artykułowanej postaci jest dopiero dostępna. Dowody istnienia Boga $\mathrm{w}$ tej postaci zakładają raczej religię, a tym samym rozumienie podstawowych religijnych treści znaczeniowych ${ }^{15}$. Musimy już wiedzieć co rozumiemy przez „Boga”,

13 Por. Der Gottesbeweis und die Phänomenologie der Religion, ss. 315-316 i przypis $\mathrm{nr} 2$.

${ }_{14} \mathrm{~W}$ artykule Filozoficzne poznanie Boga a możliwość ateizmu podobnie wyjaśnia on problem filozoficznego poznania Boga: „Stanowi ono (dowodzenie) teoretyczne ujęcie owego podstawowego stosunku, od którego wychodząc umysł ludzki zgodnie $z$ przyrodzeniem skłonny jest jeszcze przed wszelkim pozytywnym objawieniem podnosić wzrok ku Przedwiecznemu", s. 468.

15 Tego rodzaju pierwotność religii w stosunku do filozofii podkreślają m.in. August Brunner, Die Religion. Eine philosophische Untersuchung auf geschichtlicher Grundlage, Freiburg, 1956, s. 102; Henry Duméry, Le problème de Dieu en philosophie 
abyśmy mogli o niego pytać. Dowody jednak istnienia Boga stanowią teoretyczną i podstawową artykulację pierwotnie danego nam dostępu do dziedziny świętości ${ }^{16}$. Starają się one dosięgnąć świętą rzeczywistość Boga w tym duchowym miejscu, gdzie jest ona najpierw dostępna dla ludzkiego umysłu, jakkolwiek przy pomocy środków refleksji, które faktycznie nigdy nie są pierwsze. Tak rozumiane dowody istnienia Boga nie stanowią początków religii, ale dokonuje się w nich (albo winno się dokonać) myślowe ujęcie początków religii (das Denken dieses Anfangs der Religion) ${ }^{17}$.

Jeśli dowody istnienia Boga tak są ujęte, to z punktu widzenia problematyki fenomenologicznej musi być wymagane, aby w trakcie ich rozwinął się noumenalny eidos Boga jako Boga, Świętego jako Świętego. Oznacza to równocześnie, że myśl w trakcie tego dowodzenia i przez nie zostanie doprowadzona do tej podstawowej postaci, która odpowiada myśleniu o Swiętym jako o Swiętym, i że sama tym samym będzie religijna. Jeśli dowody istnienia Boga wykazują rzeczywistość Boga w pierwotnie nam dostępnym miejscu, oznacza to również, że musi się w nich dokonać rozjaśnienie pierwotnej postaci noumenalnej, podstawowej treści religijnej. Skąd bowiem mają otrzymać te podstawowe znaczenia swój pierwotny sens jak nie stamtąd, gdzie ta rzeczywistość jest dla nas najpierw do-

de la religion, Paris, 1956, ss. 14-15, a także Gilson. Ten ostatni z punktu widzenia historyka stwierdza: ,...bogowie i czynnik boski znacznie wyprzedzily filozofów, i to nie tylko u ludów zwanych ,pierwotnymi”, z których wiele nigdy filozofii nie miało posiadać, ale nawet u Greków, u których obserwowaliśmy, jak po raz pierwszy pojęcie Boga filozofów i uczonych wyłoniło się wyraźnie z mitologii ludowych, choć przeciw nim”, Byt i Bóg, s. 319. Równ. Elementy filozofii chrześcijańskiej, Warszawa, 1965 , s. 45.

16 Podobnie Maritain: „Il apparaît donc que les preuves philosophiques de l'existence de Dieu, disons les cinq voies de Thomas d'Aquin, sont un développement et une explicitation de cette connaissance naturelle, - au plan de la discussion scientifique et de la certitude scientifique. Et elles présupposent normalement cette connaissance naturelle, non en ce qui regarde la structure logique de la démonstration, mais en ce qui regarde la condition existentielle du sujet pensant", Approches de Dieu, Paris (bez daty), s. 19. Por. równ. tamże, ss. $27-28$.

17 Nie ulega wątpliwości, że Welte - interpretując $w$ ten sposób dowody istnienia Boga - zmierza się tutaj z zarzutem Heideggera wysuniętym przez niego pod adresem zachodniej metafizyki, która według niego nie mówiła o ,,boskim Bogu”, ale ujmowała Go jako jeden z bytów „które są” i w stosunku do którego czyste istnienie (Sein) jest pierwotniejsze. Por. Über den Humanismus, w: Platons Lehre von der Wahrheit, Bern, 1947, s. 77; równ. Die Gottesfrage im Denken Heideggers, s. 268-269. - Na innym miejscu Heidegger stwierdził: „Zu diesem Gott kann der Mensch weder beten, noch kann er ihm opfern. Vor der Causa sui kann der Mensch weder aus Scheu ins Knie fallen, noch kann er vor diesem Gott. musizieren und tanzen", Die Onto-theo-logische Verfassung der Metaphysik, w: Identität und Differenz, Pfullingen, 1957, s. 70. - Cyt. za: Die Gottesfrage..., ss. 272-273. - Por. równ. Odette Laffoucrière, Le Destin de la Pensée et „La Mort de Dieu" selon Heidegger, La Haye, 1968, ss. 242-244. - W dużej mierze do Heideggera nawiązywał jego kolega z Marburga Paul Tillich. Por. m. inn. Maurice Corvez, La „Théologie philosophique” de Paul Tillich, „Revue Thomiste”, LXX (1970), ss. 75-76. 
stępna? Dowody istnienia Boga mają nie tylko pozostawać w zasięgu fenomenu religijnego, ale mają dostarczać wyjaśnienia tej dziedziny i jej pochodzenia ${ }^{18}$.

b) Stanowisko E. Gilsona.

Gilson podkreśla również i to bardzo mocno pierwotność dziedziny religijnej w stosunku do poznania filozoficznego. ,Spontaniczne poznanie - pisze on - które wychodzi z pewnego rodzaju premetafizyki i poprzedza wszelką refleksję krytyczną... należy do sacrum”... ,Rzeczywistość sacrum zaczyna się z samym Sacrum; rzeczywistość divinum zaczyna się z chwilą pojawienia się czegoś z Boga, a to następuje wtedy, gdy w świadomości najbardziej nawet mglistej, byle tylko była ludzką, dochodzi do głosu poczucie transcendentnej obecności zasady tego, co jest. Powszechna zgoda jest jedna, mimo różnorodności form, w jakich się wyraża. Zgoda ta niczego nie dwodzi, ani też nie jest do udowodnienia; wyraża raczej samą religię naturalną nie tylko jako instytucję, ani jako obrzęd, ani téz jako świadomy wyraz jakiegokolwiek poznania lecz bez żadnej osłony w prostym stosunku czlowieka do Boga". - Gilson dodaje, że „,rzeczywistość tę filozof powinien przemyśleć i sformułować przy pomocy terminów dostępnych intelektowi”. Co więcej, Gilson uważa, że „nie można pomijać tego podłoża spontanicznego wnioskowania, jeśli nie chce się zatracić prawdziwego znaczenia dowodów czyli dróg, które zastosował Tomasz z Akwinu w dyskusji nad tym zagadnieniem". Zdaniem Gilsona ,istnieje więc rodzaj spontanicznego wnioskowania, dalekiego od techniki logicznej, lecz całkowicie świadomego swego znaczenia, dzięki któremu każdy czlowiek dochodzi do pojęcia transcendentnego Bytu tylko na podstawie obserwacji wzbudzającego cześć majestatu przyrody. We fragmencie zaginionego dzieła sam Arystoteles zauważa, że człowiek czerpie swe pojęcia Boga z dwu źródeł, mianowicie z własnej duszy oraz z uporządkowanego ruchu gwiazd. Jakkolwiek by było, sam fakt nie ulega wątpliwości, a systemy filozoficzne późno odkryły pojęcie Boga" ${ }^{19}$. Przeczy on jednak, by filozoficzne dowody istnienia Boga pozostawaly w zasięgu fenomenu religijnego i miały dostarczać wyjaśnienia dziedziny religijnej i jej pochodzenia. Zdaniem jego: ,spontaniczne poznanie Boga nie jest elementarnym dowodem”... ,pierwotne pojęcie Boga lub elementu boskiego lub sacrum, krótko mówiąc czynnika nadprzyrodzonego niezależnie od sposobu jego ujęcia, nie należy do tego samego porządku, co późniejsze dowody na istnienie Boga, ani też nawet nie ma tego samego przedmiotu" 20. - Gilson utrzymuje dalej w imię różnicy między elementem filo-

18 Der Gottesbeweis ..., s. 318.

19 Byt i Bóg, ss. 320-322; Elementy filozofii chrześcijańskiej, s. 44; Por. równ. Bóg i filozofia, Warszawa, 1961, ss. 100-101.

20 Byt $i$ filozofia, s. 320. 
zoficznym a elementem religijnym, że ontologia filozofa, o ile odrzuca rozważanie wszystkiego, co jest poza jej właściwym przedmiotem, czyli inaczej mówiąc, o ile postanawia w żadnym momencie nie przekroczyć granic filozofii, choćby tylko dla spojrzenia w przelocie poza swą własną granicę, tym samym zamyka sobie definitywnie dostęp do Boga religii". Gilson występuje przeciwko teologom, którzy są odmiennego zdania i uważają, że „nie można wysuwać powyższego twierdzenia bez narażenia się na oskarżenie o negowanie możliwości filozoficznych dowodów na istnienie Boga. Mylą się oni jednak..." - jego zdaniem.

W konsekwencji Gilson utrzymuje, że Bóg poznania filozoficznego jest tylko Bogiem uczonych i filozofów. Według niego Bóg religii posiada przede wszystkim dwie właściwości: jest „osobą” i jest „,transcendentny”. „Niezależnie od wszelkiego objawienia nadprzyrodzonego - pisze on właściwe religijne pojęcie Boga, jakiegoś boga albo nawet bogów, zakłada najpierw pojęcie tego, co nazywamy osobą, a co można po prostu nazwać „,ktoś”. Bóg to jest ktoś lub coś, wobec czego zachowujemy się jak wobec kogoś. W tym sensie najmniejsza statuetka, najbardziej niewyszukany fetysz, należy pełnoprawnie do dziedziny religijnej, podczas gdy substancja Spinozy należy do porządku filozoficznego”. — „Drugą właściwością Boga religii jest fakt, że zawsze jest bezpośrednio przyjmowany jako transcendenty. Jakkolwiek się Go pojmuje, zawsze posiada On władzę oddziaływania dodatnio lub ujemnie na losy człowieka. Ta druga cecha jest pierwszym źródłem całkowicie rozwiniętego pojęcia Boga bezwzględnie transcendentnego wobec porządku rzeczywistości fizycznej i będącego jego przyczyną. Nie ma religii bez Boga Twórcy wszechświata, lecz ta druga cecha Boga religii precyzuje się stopniowo..."

Gilson przyznaje, że filozofia może dojść do Boga jako bytu transcendentnego ,to jednak przeczy, by dochodziła przez to do Boga religii: ,„Jeśli bowiem Bóg religii domaga się bezwzględnej transcendencji, wszelkie filozoficzne wykazywanie pierwszej zasady bytu równa się według teologii filozoficznemu dowodowi istnienia Boga. I nie bez powodu. Jeżeli bowiem Bóg religii istnieje i jeśli Bóg filozofii istnieje, stanowią jedno, z czego jednak nie wynika, że filozofia dochodzi do Boga religii, ani, że Bóg religii sprowadza się do pierwszej zasady filozofii. Jeśli nawet filozofia określa Boga jako transcendentny, co nie dzieje się w każdym wypadku i co nawet niechętnie czyni, pierwsza zasada pozostaje z definicji zasadą natury. Określana jest $\mathrm{w}$ oparciu o rzeczy i jako ich przyczyna - oto jak ją ujmuje filozof. Teologia nie spodziewa się więc swego Boga od filozofii i nie sądzi, żeby Go jej zawdzięczała, ale Go przyjmuje i nadaje Mu rysy nadprzyrodzone" 21.

21 Byt $i$ filozofia, ss. 328-330. - Duméry, który stoi także na stanowisku, że filozof nie jest autorem idei Boga, ale tym, który na nią natrafia (por. przy- 


\section{c) Uwagi i zapytania.}

Jak więc można zauważyć, pomiędzy stanowiskiem Weltego a Gilsona zachodzi zasadnicza różnica. Zdaniem pierwszego, przeciwstawiającego się Heideggerowi, dowodzenie istnienia Boga, jeśli się uwzględni jego aspekt fenomenalny, prowadzi nas do prawdziwego Boga religii. Gilson przeciwnie, utrzymuje wprawdzie podobnie jak Welte, że filozofia nie tworzy pojęcia Boga, ale ponadto, że dowodzenie istnienia Boga nie dosięga Boga religii.

Po czyjej stronie wypadnie nam się opowiedzieć? Dalsze analizy dowodzenia istnienia Boga od strony fenomenalnej winny dostarczyć nam rozwiązania problemu. Naszym zdaniem bowiem rozstrzygnięcie zagadnienia zależy od stosunku, jaki zachodzi pomiędzy spontanicznym poznaniem człowieka a ściśle filozoficznym.

Jeśli uznamy za Weltem, że dowody istnienia Boga stanowią teoretyczną artykulację pierwotnego procesu, który jest natury religijnej, albo jak to określa Maritain, że dowody filozoficzne św. Tomasza są rozwinięciem i wyjaśnieniem w płaszczyźnie naukowej i pewności naukowej poznania naturalnego, które opierając się na intuicji mojego istnienia i istnienia świata rzeczy, polega na skrótowym, spontanicznym, naturalnym jak sama ta intuicja rozumowaniu ${ }^{22}$, - to zdają się one dowodzić nie tylko Boga filozofów i uczonych (poznanie naukowe i refleksyjne), ale też Boga religii, która jest właściwością człowieka, jedynego zwierzęcia rozumnego ${ }^{23}$.

Nie oznacza to wcale utożsamienia pơrządków religijnego i filozoficznego. Mówiąc o religii, mamy na uwadze nie religię opierającą się na Objawieniu nadprzyrodzonym, ale tę postawę człowieka, która polega na posiadaniu przez prawie wszystkich ludzi — jak utrzymuje św. Tomasz „,pewnego ogólnego i niejasnego poznania Boga”. Zdaniem św. Tomasza to poznanie Boga zdaje się być owocem rozumu naturalnego ${ }^{24}$. Tak pojęta religijność stanowi dziedzinę życia człowieka. Dowodzenie - nie jest religią. Stanowi dziedzinę refleksji. Ale — tak ujęte - ujmuje w płaszczyźnie poznania rozwiniętego i uściślonego ten wymiar religijności naturalnej, który wiąże się z rozumem naturalnym, jako czynnością spontaniczną, nie refleksyjną. Możemy powiedzieć, że refleksja odkrywa

pis 15), odrzuca podział Pascala na Boga filozofów i Boga wierzących. Nie ma ani Boga filozofów ani Boga tradycji. Jeśli jest antyteza (nie antynomia) to tylko w płaszczyźnie teizmu przeżywanego i refleksyjnego. Por. Le problème de Dieu, ss. 16; 18.

22 ,...les preuves philosophiques de l'existence de Dieu sont comme un épanouissement ou un développement décisif, au niveau du savoir rationnel de type „scientifique" ou ,parfait" de la connaissance naturelle pré-philosophique impliquée dans l'intuition primitive de l'acte d'être, Approches de Dieu, s. 28; por. równ. przypis 16.

23 Byt i Bóg, s. 322.

24 Contra Gentes, III, 38. 
wtedy strukturę logiczno-racjonalną tkwiącą w czynnościach spontanicznych człowieka (jeśli religia nie jest czymś całkowicie irracjonalnym) ${ }^{25}$ i nawiązuje do metafizyki w człowieku (Dondeyne), lub jak określa to Gilson „premetafizyki” (która n. b. jego zdaniem - posiada religijny charakter). W tym - hipotetycznym na razie - ujęciu, które wydaje się nam prawdopodobne, należy dodać, że religijność ze swej strony implikuje metafizyczny wymiar egzystencji człowieka. Metafizyka więc nie tworzyłaby swego Boga (ani religia nie zawdzięczałaby Go metafizyce), ale eksplikowałaby ona ten pierwotny wymiar metafizyczny zawierający się w religijności naturalnej i ujmowałaby Go swoimi środkami.

Gilson - jak widzieliśmy - reprezentuje jednak tutaj stanowisko przeciwne. Nie wydaje się ono całkiem słuszne i konsekwentne, zwłaszcza gdy się uwzględni to, co pisze on w wyżej przytoczonym tekście na temat spontanicznego wnioskowania, dzięki któremu człowiek dochodzi do pojęcia Boga i porówna się je $z$ tokiem dowodów na istnienie Boga u św. Tomasza. - Zanim przejdziemy już do samej analizy dowodów i niezależnie od niej pod adresem Gilsona nasuwają się następujące pytania:

Jeżeli „rzeczywistość divinum - jak twierdzi Gilson - zaczyna się z chwilą pojawienia się czegoś z Boga, a to następuje wtedy, gdy w świadomości najbardziej nawet mglistej, byle tylko była ludzką, dochodzi do głosu poczucie transcendentnej obecności zasady, tego co jest" ${ }^{26}$, to czy do tego samego nie prowadzą nas dowody istnienia Boga? A jeśli tak na co Gilson częściowo sam musi przystać - to dlaczego nie ma On być równocześnie Bogiem religii? Jeśli teologia anektuje Go dla siebie, to czy nie dlatego, że odnajduje ona swego Boga w poznaniu uściślonym i rozwiniętym? Czy do uświadomienia, że ma się do czynienia z Bogiem — choć rozważanym w aspekcie bytu - potrzeba wpływu z zewnątrz, tak jak głosi Gilson, jeśli się poznaje ten sam przedmiot? - Gdyby było tak, jak głosi Gilson, jak w takim razie wytłumaczyć religie z istoty swej filozoficzne i filozoficzną nabożność?

Jeśli nawet przyjmie się za Gilsonem, że ,szczyt poznania filozoficznego, pierwsza przyczyna, względnie pierwsza zasada nie jest transcendentna w stosunku do porządku filozofii”, „,natomiast pojęcie sacrum, divinum i Boga zdają się posiadać inne źródło", to czy przedmiot, który osiąga się na dwóch różnych drogach (aspekty formalne) nie jest ten sam? Filozofia nie potrzebuje przekraczać swej granicy, aby dosięgnąć Boga (religii). Jako dzieło rozumu, ma ona otwartą do Niego drogę, tak samo jak rozum naturalny, spontaniczny, i tak jak on, doświadczając swoich

25 Por. równ. Duméry, Le problème de Dieu, s. 18.

26 Byt i Bóg, s. 321. 
granic w tej dziedzinie ${ }^{27}$. Jeśli teolog anektuje Boga, do którego dochodzi filozof, to filozof - wydaje się nam - ze swej strony anektuje dla siebie Boga religii. I tak właśnie postępuje św. Tomasz. Jeśli niezależnie od wpływu psychologicznego, jego dowodzenie Boga posiada charakter czysto rozumowy i nie chcemy mieszać genezy historycznej $\mathrm{z}$ genezą logiczną, to tutaj nie teolog ale filozof domaga się uznania dla kresu swego poznania nazwy Boga 28.

Nasze uwagi i zapytania nie rozstrzygają — jak zaznaczyliśmy - samego zagadnienia. Posiadają one charakter hipotetyczny. Aby rozstrzygnąć zagadnienie stosunku pomiędzy Bogiem religii a filozofii należy obecnie przystąpić do analizy dowodu istnienia Boga od strony przede wszystkim zawierającego się w nim aspektu fenomenalnego.

\section{DOWODY SW. TOMASZA A DZIEDZINA RELIGII}

Welte zauważa, że dowody św. Tomasza w tej postaci, w jakiej nam są dane, nie robią wrażenia, by czyniły zadość wyżej wspomnianemu postulatowi fenomenologii. Zdają się one raczej różnić od dziedziny fenomenu religii. Dowody prowadzą do primum movens, quod in nullo movetur, do causa efficiens prima... Wszystkie te określenia w swej bezpośredniej postaci nie podpadają pod dziedzinę fenomenu religii. Tomasz czyni jednak przejście do dziedziny religijnej, kiedy potem dodaje: et hoc omnes intelligunt Deum, albo: quam omnes Deum nominant. Przez te uzupełnienia Tomasz - zdaniem Weltego - zdaje się wskazywać, że to przejście do Boga jako Boga nie dzieje się, w każdym razie nie wyłącznie, na mocy samych dowodów istnienia Boga, w tej formie w jakiej są prezentowane. Jest $\mathrm{w}$ tym miejscu pewne uzupełnienie. Sw. Tomasz nie wyjaśnia bliżej, gdzie leży podstawa tego przejścia. Dlaczego to, co jest określone w dowodach od strony metafizycznej, wszyscy ludzie nazywają Bogiem. Welte utrzymuje jednak, że gdy nie pozostajemy tylko przy zewnętrznej szacie dowodów istnienia Boga, lecz gdy staramy się je ując w ich pełnym wymiarze, to wtedy ten proces myślowy prowadzi do dziedziny fenomenu religii i że w samej myśli wskazuje na możliwość takiego przejścia. I to właśnie chce ukazać w zarysie w swej rozprawie Welte. Chodzi o przebadanie dowodów istnienia Boga od strony zawierającego się w nich momentu fenomenalnego ${ }^{29}$.

\footnotetext{
27 Por. zwłaszcza: Jean Daniélou, Dieu et nous, Paris, 1956; tłum. polskie: Bóg i my, Kraków, 1965, ss. 41 ns.

${ }_{28}$ Van Riet w art. Foi et Réflexion philosophique, s. 44, zam., w: Foi et Réflexion philosophique, Louvain, 1961, zwraca uwagę na zarzuty podnoszone przeciw Gilsonowi, a mianowicie, nie uwzględnienie przez niego przedmiotów formalnych.

${ }_{29}$ Der Gottesbeweis ..., s. 319.
} 
Stanowisko w tym względzie Weltego - jak postaramy się to pokazać - jest słuszne. Dowody istnienia Boga, gdy ujmujemy je w pełnym wymiarze, prowadzą nas do fenomenu religii. Powstaje jednak pytanie, czy św. Tomasz stwierdzając przy każdej z pięciu dróg: et hoc omnes intelligunt Deum, albo: quam omnes Deum nominant, zdaje się przez to wskazywać, że to przejście dokonuje się nie na mocy samych dowodów? jak to sugeruje Welte. Nie koniecznie. A nawet wydaje nam się, że jest przeciwnie. To prawda, że kresy poszczególnych pięciu dróg w swej bezpośredniej, zewnętrznej postaci zdają się różnić od fenomenu religii. Odczytanie jednak pełnej treści, którą implikują terminy: primum movens, causa prima, ens necessarium... pozwalało św. Tomaszowi na dostrzeżenie w nich Boga chrześcijan.

Ten właśnie aspekt dowodów zechcemy ukazać po przeanalizowaniu samego procesu myśli, który stanowi ich osnowę, tkankę. Pod tym względem idziemy więc dalej niż Welte. Nie tylko abrewiatura dowodzenia kryje $\mathrm{w}$ sobie proces natury religijnej, ale $\mathrm{i}$ abrewiatura filozoficznych terminów u kresu pięciu dróg kryje w sobie Boga religii.

\section{PODSTAWOWA STRUKTURA DOWODÓW ISTNIENIA BOGA OD STRONY FENOMENALNEJ}

\section{a) Punkt wyjścia i zasada dowodzenia.}

Wszystkie sformułowania dowodów istnienia Boga u św. Tomasza są rozwinięciem i ilustracją jednej podstawowej myśli — zauważa Welte. Jest ona zawarta w Ente et essentia, w r. V. Brzmi ona: ,oportet quod sit aliqua res, quae sit causa essendi omnibus rebus eo, quod ipsa est esse tantum"; ,alias iretur in infinitum in causis, cum omnis res, quae non est esse tantum, habet causam sui esse".

$\mathrm{Na}$ podstawie tego krótkiego tekstu można dostrzec, że kierunek dowodzenia istnienia Boga zawiera się między dwoma podstawowymi terminami esse tantum i res quae non est esse tantum. Terminy te oznaczają u św. Tomasza nie tylko wynik dowodów, ale i ich punkt wyjścia, zasadę ${ }^{30}$. Stosunek pomiędzy tymi dwoma określeniami stanowi nerw dowodzenia istnienia Boga. Stąd Welte chce zwrócić baczną uwagę na pierwotną postać i bezpośrednie dane tych określeń i ich stosunek.

Św. Tomasz określa rzeczy, od których wychodzi dowodzenie istnienia Boga, przez ich różnicę od tego co określa on jako esse tantum. Tę róż-

30 Podobnie Maritain. Uważa on, że wszystkim dowodom istnienia Boga jest wspólna ta sama zasada formalna: ,... le nerf de la preuve ou le principe formel de la démonstration est le même dans les cinq voies: l'exigence d'une première cause qui est l'acte pur ou l'Etre même subsistant par soi. Sous ce rapport on pourrait dire qu'elles ne sont qu'une seule preuve présentée sous des modes ou des aspects différens", Approches de Dieu, ss. 31-32. 
nicę możemy także określić pozytywnie jako związek: rzecz, która nie jest esse tantum, jest tą, której przysługuje istnienie, cui convenit esse.

Jak więc ujęta jest rzecz stanowiąca punkt wyjścia dowodów? Dokładnie: o ile ona jest - a więc w aspekcie bytu. Słowo ,jest” oznacza bowiem, że istnienie dochodzi do niej. Wszystkie pojedyncze punkty wyjścia jak ens mobile, ens possibile są tylko przykładowymi rozwinięciami tego podstawowego określenia, że rzecz jest ${ }^{31}$.

b) Sposób ukazywania się rzeczy jako istniejącej i odpowiadająca jej myśl.

Fenomenologiczny punkt widzenia nakazuje nam zapytać: w jaki sposób to, że rzecz jest, pierwotnie się ukazuje, jak dochodzi do fenomenologicznego rozwinięcia jego własnego noema? I jaki jest akt, w którym dokonuje się to ukazywanie się? Trzeba więc zwrócić baczną uwagę na to, jak to, że coś jest, staje się pierwotnie fenomenem?

W zwróceniu się intelektu do wyobrażeń (conversio intellectus ad phantasma) zajmujemy się określonymi istotami rzeczy i tylko in confuso dochodzi do nich, że jako takie sa. Myślimy o ludziach, książkach. „Jest” pozostaje jednak jeszcze w ukrytej fenomenalności i nie otwiera się łatwo w swoich własnych rozmiarach ${ }^{32}$. Aby wystąpiła własna fenomenalność ,jest” i aby w pełnej postaci i mierze się ono ukazało, do tego konieczne jest pewne negatywne postępowanie, pewne przyzwolenie, pewna redukcja. Myśl musi się oderwać od determinacji istotowych. „Jest” nie jest bowiem żadną determinację istotową. Nie jest żadnym rodzajem, jak podkreśla św. Tomasz. Myśl musi się bezwzględnie otworzyć na istnienie i stać się podatną na to, że w ogóle jest, co jest.

Ujmując wszystko jako to, co jest, myśl dosięga koniecznie istnienia samego myślącego i aktualnego istnienia jego myśli ${ }^{33}$. Wszystko objęte jest tym, że jest, co jest. „Wszystkie rzeczy i wszystkie wzajemne stosunki wszystkich rzeczy - wszystko to jest. To, co wyraża słowo ,,jest", stanowi przenikającą wszystko cechę podstawową naszego bytowania. Przenika każdą poszczególną rzecz i każdy poszczególny stosunek. Włada też tak, że ogarnia całość mnie w moim świecie, mój świat dla mnie. To

31 Der Gottesbeweis ..., s. 320.

$32 \mathrm{Na}$ swój sposób opisuje ten proces Maritain: „Sortons donc du sommeil, cessons de vivre dans les rêves ou la magie des images et des formules, des mots, des signes et des symboles pratiques. Quand un homme a été éveillé à la réalité de l'existence et de sa propre existence, quand il a réellement perçu ce fait formidable, parfois enivrant, parfois écoeurant ou affolant: j'existe, il est désormais saisi par l'intuition de l'être et les implications qu'elle comporte," Approches de Dieu, ss. $11-12$.

33 Zdaniem Maritaina właśnie w poznaniu naturalnym, spontanicznym, pierwotna intuicja aktu istnienia jest równocześnie intuicją własnego istnienia i istnienia rzeczy: ,cette intuition primordiale est à la fois l'intuition de mon existence et de l'existence des choses," j. w., s. 12. 
jest tak, że oto $\mathrm{w}$ ogóle jestem $\mathrm{w}$ moim świecie, że oto $\mathrm{w}$ ogóle świat jest dla mnie, że w ogóle, wszystko ogarniając, jest to co jest" 34 .

Sama myśl, będąc objęta tym, że jest, co jest, musi tym samym różnić się w sposób specyficzny od abstrahującej i obiektywizującej formy myślenia ${ }^{35}$.

Wszystko to, że jest, co jest i odpowiadająca temu myśl, jest czymś całkowicie prostym. W myśli tej pomyślane jest wszystko, ale nie jako wielość, ale jako coś całkowicie jedno, że jest, co jest. Wszystko jest zebrane w jedno, ponieważ jest. Odpowiadająca temu myśl sama przybiera postać jedności i skupienia.

Zwrócenie się zaś do tego, że jest, co jest, jest jak wyraźnie widzi św. Tomasz początkiem pojawienia się Boga w myśli. Jeśli bowiem pozwalamy rozwinąc się właściwym wymiarom tego, co ,,jest”, to wtedy dochodzimy do szczególnej postaci duchowej noezy, myśli wewnątrz której noema tego ,,jest" rozwija się w swej właściwej postaci, a nie tylko w sformalizowanej abrewiaturze. Już w tej początkowej fazie rozważania możemy rozpoznać, że zbliżamy się w bardzo charakterystyczny sposób do fenomenalnej dziedziny pierwiastka religijnego przez to samo, że samej rzeczy o którą tutaj chodzi i o której św. Tomasz mówi, pozwalamy się rozwinąc $\mathrm{w}$ myśli zgodnie $\mathrm{z}$ jej istotą. Staramy się przy tym iść za tym rozwinięciem bez zewnętrznych czy subiektywnych uzupełnień (dodatków).

Od tego punktu, transcendencja rzeczy tego, co jest, na którą św. Tomasz wskazuje, nabiera w myśli transcendentującego ruchu, w kierunku ipsum esse. Ten transcendentujący ruch myśli, który bierze początek od tego, że jest, co jest, posiada różne pierwotne postacie, spośród których wyróżniają się zdziwienie i pytanie.

Myśl skupiona nie pozostaje przy tym, że jest, co jest. Sam ten fakt wprawia ją w zdziwienie i pytanie: jak to się dzieje, że w ogóle coś jest? ${ }^{36}$ Jak to jest $z$ istnieniem bytu? Dlaczego w ogóle coś jest? ${ }^{37}$

W tego rodzaju poruszeniu dokonuje się transcendencja ,jest”, ale nie w tym znaczeniu, że pozostaje ono opuszczone. Przeciwnie, okazuje się, że jest co jest, jest samo najbardziej godne podziwu i badania. Transcendencja nie leży poza nim, lecz tworzy jego własną głębię.

\footnotetext{
34 Filozoficzne poznanie Boga a możliwość ateizmu, s. 469.

35 Filozoficzne poznanie Boga a możliwość ateizmu, s. 469. - Równ. Tomizm, s. 506 .

36 Gilson polemizując z Heideggerem także podkreśla moment zdziwienia w obliczu istnienia rzeczy (,,to, co jest" jest), ale równocześnie i punkt w którym Bóg wkracza do filozofii: „Ow bolesny lęk, przypominający zawrót głowy ogarnia człowieka z chwilą, gdy dostrzega - jako jedyny byt zdolny to uczynić - ów cud nad cudami, że „to, co jest”, jest (Was ist Metaphysik, s. 47). Nie ma w tym jednak nic nowego. Właśnie w tym przymusowym milczeniu w obliczu Est onto-teologowie upatrywali punkt, w którym Bóg wkracza do filozofii” (jest to także jeden z problemów wysuniętych przez Heideggera), Byt i istota, s. 328.

37 Der Gottesbeweis ..., ss. 323-324; Filozoficzne poznanie Boga..., ss. $471-472$.
} 
W zdziwieniu i pytaniu odnośnie istnienia rzeczy ta postać myśli, która została określona jako przyzwolenie, prostota i skupienie także nie zostają opuszczone. I ta noetyczna postać $\mathrm{w}$ zdziwieniu i pytaniu osiąga swoistą, jej przynależną głębię.

Co dokonuje się $\mathrm{w}$ tego rodzaju poruszeniu polegającym na zdziwieniu i pytaniu', że w ogóle coś jest. W ,,jest” rozwija się różnica. Polega ona na tym ,że to ,jest" non est suum esse ${ }^{38}$. To co jest godne podziwu i zastanowienia jest samo przez się nie zrozumiałe. Ukazuje się ono jako oddalone i różniące się od normy i podstawy samozrozumialności; oddalone od punktu zero i normy istnienia. Nie potrzebuje być, nie da się pojąć, że jest, co jest, ale o dziwo: jest. - Zadziwiona myśl poza pozorną powierzchownością, ,jest” dostrzega wewnętrznie przyporządkowane mu coś innego (różnicującego) jako nieskończoną tajemnicę ${ }^{39}$.

Różnica tego, co jest, jest różnicą w stosunku do miary, normy, podstawy istnienia, a tym samym zrozumienia. To, co jest różni się od czegoś, co jest samym istnieniem, bez zróżnicowania, i przez to samo w tym sensie musimy je nazwać absolutnym. - W pytaniu i zdziwieniu okazuje się, że rzeczy są tylko dzięki absolutnemu Bytowi ${ }^{40}$.

c) Kres poznania: Nieskończona Tajemnica i miejsca jej ukazywania się.

Jak wielkie i jaką istotę posiada ukazujące się nam w tym zdziwieniu i pytaniu to Inne, ta Transcendencja, Miara i Podstawa w ogóle istnienia i rozumienia. Ukazuje się nam ono jako obejmujace wszystko to co jest i jako ponad tym wszystkim, bez granic, przekraczające to, co jest. To samo stwierdza Maritain: - to, czego dowodzimy, dowodząc istnienia Boga, to to, co nas nieskończenie przekracza, nasze idee i nasze dowody ${ }^{41}$.

Gdzie tego rodzaju myśl i pytanie odnajduje absolutną nieskończoność? Miejscem, w którym ta nieskończoność się pojawia jest fenomenalnie najpierw sama rzecz jako taka (konkretny byt). Rzecz bowiem (istniejąca) jest sama fenomenem nieskończenie godnym podziwu. Jej różnica w stosunku do transcendentnej podstawy i racji istnienia i zrozumienia, która występuje fenomenalnie w zdziwieniu nie oddziela jej od tej transcendencji.

Fenomenalne miejsce występowania tej zadziwiającej nieskończoności jest tym samym wnętrze samego zadziwionego i samej jego myśli.

Poza tym staje się widocznym, że tajemnica nieskończoności jeszcze bardziej w wewnętrzny sposób określa nasze własne życie. Jest ona ponad

3n Der Gottesbeweis ..., s. 325 i przypis tamże, nr 6 .

39 Por. równ. Maritain, Approches de Dieu, ss. 12-13.

40 Por. równ. j. w., ss. 14-15.

41 J. W., S. 21. 
naszą uformowaną myślą i pytaniem, jako je umożliwiająca. Myślenie, pytanie, zdziwienie, a więc pierwotne nasze życie duchowe, powstają same ze siebie, tzn. z pierwotnego początku. Analiza jednak pokazuje nam, że właśnie nieskończona miara istnienia, którą mierzymy już rzeczy istniejące, pobudza i umożliwia to życie.

Nieskończona tajemnica jest już w nas, wprawdzie nie na sposób czegoś pomyślanego, nie na sposób „wrodzonej idei”, lecz jako ciche założenie dla wszystkich rozstrzygających i początkowych pytań i zadziwienia i przez to samo w ogóle dla życia duchowego i myśli. — „Najbardziej jednak tajemnicze w tej sytuacji jest to, że my myślący ludzie — zauważa Welte — stojąc w obliczu problematyczności istnienia bytu przed naszym wielkim pytaniem, najwyraźniej już całościowo oceniamy czy też określaliśmy istnienie bytu według miary, jaka nie jest nam obca, choć wymyka się ujęciu. Nie pytalibyśmy i nie moglibyśmy pytać, dlaczego w ogóle coś jest, a nie nic, gdybyśmy tego, że coś jest, nie odczuwali jako odbiegającego od naszej pełnej potencjalnej miary rozumienia istnienia bytu, jako, że wbrew pozorom nie dopełnia to owej miary.

W samej głębi naszej myśli czeka więc i żyje coś, w zetknięciu z czym słowa ,istniejący" czy nie istniejący ześlizgują się i nic już nie znaczą. W tajemniczy sposób nie jest nam obce owo coś, czego nie potrafimy pojąć ani wypowiedzieć, a co jednak w niepojęty sposób woła ku nam ze wszystkiego i ponad wszystkim, co istnieje" ${ }^{42}$.

Jest to także jeszcze jeden powód, że przy pierwotnym zastanawianiu się nad cudownością istnienia chodzi w najwłaściwszym sensie o mnie i o coś najgłębszego w moim życiu.

Podkreślenie tego momentu przez Weltego - jak łatwo zauważyć ma szczególne znaczenie. Uwidacznia bowiem związek Nieskończonej Tajemnicy z tym, co jest najgłębsze w człowieku, a nie tylko jej odniesienia do świata, do natury. Aspekt religijny - zależność mojego losu — na co zwraca uwagę Gilson - przybiera tutaj najpełniejszy wymiar.

Pytanie jednak rodzi się, w stosunku do Weltego, jak należy pojmować ową obecność w nas Nieskończonej Tajemnicy, jako koniecznego założenia dla naszej myśli, i dla całego życia duchowego: „,ze w tajemniczy sposób nie jest nam obce owo coś, czego nie potrafimy pojąć ani wypowiedzieć, a co jednak w niepojęty sposób woła ku nam z wszystkiego i ponad wszystkim, co istnieje”, że ,Nieskończona Tajemnica jest już w nas jako ciche założenie dla wszystkich rozstrzygających pytań, w ogóle dla życia duchowego".

Stanowisko Weltego jest zresztą tutaj nie całkiem jasne. Welte zastrzega się, że nie można tej obecności w nas pojmować na sposób wrodzonej idei. Podkreśla również, że zdziwienie i pytanie biorą początek

${ }^{42}$ Filozoficzne poznanie Boga ..., s. 472. 
same ze siebie. Z drugiej strony zauważa, że bez tajemniczej obecności w nas owej „miary" nie pytalibyśmy dlaczego w ogóle coś jest i nie oceniali tego, co jest.

W tym względzie wypada nam zauważyć to, co podnieśliśmy już kiedyś pod adresem Dondeyna ${ }^{43}$ nie w formie krytyki, ale w formie sprecyzowania swego zapatrywania. Jeśli przyjmiemy, że byt dany nam w doświadczeniu przez rozpoznaną w nim problematyczność odsyła nas do innego bytu ${ }^{44}$,to nie musimy już zakładać jakiejś uprzedniej obecności w nas sensu tego, co jest bytem - simpliciter prius. - Poznając problematyczność bytu prius quoad nos - dochodzimy do wytworzenia idei "Bytu Absolutnego".

Nie wykluczamy przez to związku, jaki zachodzi pomiędzy naszym życiem duchowym, a Nieskończoną Tajemnicą, że określa ona nasze własne życie i stanowi jego założenie. Człowiek doświadczając problematyczności bytu, który jest mu dany, ma do wyboru przyjąć tajemnicę albo skazać się na absurd. Wskazywał na to już swego czasu m. in. Krąpiec. Alternatywę tę na swój sposób potwierdza ateistyczny egzystencjalizm.

Ukazująca się Transcendencja ma jeszcze jedno decydujące fenomenalnie miejsce. Ukazuje się jako ponad i poza tym cokolwiek jest, a przez to samo, co mogę pojąc swoją myślą i wyrazić mową ${ }^{45}$.

d) Noeza odpowiadająca ipsum esse.

Tym samym należy stwierdzić, że w obliczu nieskończonej Transcendencji, myśl w formie pojęciowania i wyrażania jest u swego kresu ${ }^{46}$. Podstawową formę pojmowania i wyrażania, według Weltego stanowi właśnie ,jest”. Nie ma żadnego pojęcia i żadnej wypowiedzi, w której „jest" nie byłoby pomyślane i wypowiedziane. Otóż to zostaje przekroczone $\mathrm{w}$ transcendującym zadziwieniu nad istnieniem rzeczy. „Wykracza na pewno poza wszystko co ,jest”, odkąd pyta, dlaczego w ogóle coś jest" " ${ }^{47}$. Pomyślane więc jest $w$ tym przejściu to, co jest nie do pomyślenia, niepojęte, niewyrażalne. Będzie można zobaczyć, że warunkuje to zupełnie odrębną formę duchowej noezy i to $\mathrm{z}$ racji istoty tego, co staje

43 Przedfilozoficzne $i$ filozoficzne ..., ss. $344-345$.

44 Por. Religijne poznanie Boga..., zwłaszcza ss. 127-143.

45 Der Gottesbeweis ..., s. 327.

46 W tym samym duchu stwierdza Gilson: „Poznawać znaczy obejmować myślą to, co jest. Nie ma innego doskonałego poznania. Otóż jest rzeczą oczywistą, że zostaliśmy nieodwołalnie pozbawieni możliwości poznania - w pełnym tego słowa znaczeniu - wyższych stopni powszechnej hierarchii. O Bogu a nawet o czystych inteligencjach, wiemy tylko tyle, że istnieją. Nie wiemy natomiast, czym są. Skoro jednak poznanie polega na uchwyceniu istoty poznawanego przedmiotu, trzeba stwierdzić iż Bóg ... jest z samej definicji nieuchwytny dla naszego intelektu," Tomizm, ss. 498-499.

47 Filozoficzne poznanie Boga ..., s. 473. 
przed myślą. Myśl musi tutaj wkroczyć w milczenie. — „Myśleć można ściśle mówiąc to tylko, co da się ująć i określić w formie sądu, czyli w formie ,to jest”. Taki sąd określający stanowi podstawową formę ujmowania rzeczy, a także myśli samej przez siebie. Jeśli sąd taki nie ma już sensu, myśl musi się zatrzymać, rozum i jego język zamilknąć". ${ }^{48}$

Tę stronę transcendencji ipsum esse św. Tomasz wyrażał często $\mathrm{w}$ ten sposób, że esse i tym samym Bóg nie znajduje się w rzędzie jakiejkolwiek kategorii: non est in aliquo genere. Kategorie stanowią podstawowe sposoby bytowania rzeczy, podstawowe sposoby ,jest”. Przez to samo stanowią podstawowe sposoby sądów i wypowiedzi. Co nie jest w jakimś rodzaju, nie może być wypowiedziane w sądzie. Welte zaznacza, że wprawdzie możemy i musimy mówić o tym, że Tajemnica jest, Nieskończoność, Racja, Czyste Istnienie, na końcu Bóg. Musi istnieć teologia naturalna pozytywna. Będzie ona jednak posiadała szczególny stosunek do słów, albowiem właśnie jej zadaniem jest to, co jest niewypowiedziane ująć w mowę. W tego rodzaju mowie ,jest”, jako właściwie artykułujący element mowy, nie może być utrzymywane nadal w swym bezpośrednim i prostym znaczeniu. Inaczej to, co zostaje tutaj wyrażone, będzie sprowadzone do jednego $\mathrm{z}$ najwyższych rodzai. ${ }^{49}$

Wyrażenia Weltego, że $\mathrm{w}$ tego rodzaju akcie myśli przekracza się „,jest”, ponieważ podstawową formą pojmowania i wyrażania jest właśnie ,jest" i że nie ma żadnego pojęcia i żadnej wypowiedzi, w której ,jest" nie byłoby pomyślane i wypowiedziane, i tym podobne sformułowania mogą budzić zastrzeżenia w kręgach myślicieli przyzwyczajonych do terminologii tomistycznej prezentowanej np. przez Gilsona czy Maritaina. Właśnie do Boga odnosimy ,,jest”, istnieje, a wykluczamy „,to, co”, względnie stwierdzamy, że Jego esse stanowi własną quidditas ${ }^{50}$.

Aby poprawnie zrozumieć wyrażenia Weltego, należy uwzględnić, że nawiązuje on do terminologii Heiddegera, a ponadto to, co on sam rozumie przez słowo ,jest”. Welte odnosi ,jest” wyłącznie do rzeczy istniejącej, inaczej, że ,jest" stanowi tę formę bytowania, w której uwidacznia się różnica do czystego istnienia. Innymi słowy stanowi ono

48 J. w., s. 473 . - W polemice z Heideggerem Gilson stwierdza podobnie, że metafizyka dochodząc do czystego esse - musi zamilknąć - ponieważ jest w obliczu niewyrażalnego. Byt $i$ istota, s. 326. - Podobnie w Tomiźmie: (dowieść Boga) „,jest to ostateczny kres ludzkiego poznania. Kiedy stwierdzamy, że Bóg jest najwyższym istnieniem, kończy się filozofia, a zaczyna się mistyka. Mówiąc po prostu, rozum stwierdza wówczas iż wszystko, co może poznać, zakorzenione jest w Bogu, którego poznać nie może: cum Deo quasi ignoto coniungimur”, ss. 511-512.

49 Der Gottesbeweis ..., s. 328; Zwraca na to uwagę także Gilson: „By mówić o Bogu nie mamy innego języka niż ten, którym mówimy o stworzeniach, a że ten język jest już ze swej definicji nieadekwatny, każde zdanie, jakie wypowiadamy o Bogu, wymaga poprawki," Pojęcie Boga w filozofii św. Tomasza $z$ Akwinu, w: Studia $z$ filozofii Boga, s. 206.

50 Por. Maritain, Aproches de Dieu, ss. 22-23. 
formę bytu kategorialnego a nie bytu absolutnego ${ }^{\mathbf{5 1}}$. — Łatwo domyśleć się intencji, którymi kieruje się Welte. Zależy mu na tym, by wykazać, że pięć dróg św. Tomasza prowadzi do Boga ujętego nie na sposób tego co jest (Seiende) ${ }^{52}$ a więc bytu kategorialnego, ale do tego, co jest całkowicie transcendentne.

W tym też sensie - choć na swój sposób - eksplikuje Gilson pojęcie Boga w filozofii św. Tomasza: „Nie jest On ,res cui debetur non esse in aliquo' (De pot. q. VII, a. 3, ad 4). Bóg jest niezłożony, więc nie można Mu przypisywać istoty różnej od Jego istnienia. Są to słowa św. Tomasza i widać tu jasno, że wymaga on, by język filozofów wypowiedział coś, do czego nie jest zdolny. Stwierdziwszy, że Bóg, czyli „Który jest”, oznacza we właściwy sposób istotę Bożą, dodaje, że w Bogu istota nie różni się od Jego esse. A jeśli tak jest, to nie ma w Bogu niczego, co by było podmiotem aktu istnienia; nie może być substancją, gdyż Jego istota nie otrzymuje esse, ale jest tym esse. Jakże więc będziemy mogli pojąc tego Boga, który jest ponad wszelką kategorią, nie ma rodzaju ani różnicy gatunkowej, więc nie ma definicji?" - Na innym zaś miejscu Gilson wprost zaznacza, że wyraz ,,jest” zgodnie z imieniem „Który Jest” oznacza substancję i istotę ${ }^{53}$.

Możemy więc powiedzieć, że o ile Gilson w Tomaszowym pojęciu Boga podkreśla, że Bóg nie jest $\mathrm{r}$ es cui debetur non esse in aliquo, to Welte akcentuje, że w Bogu nie ma „,jest”, które zakłada odniesienie do „to, co”, nie ma ,jest", które byłoby aktem ens. Welte odmawia Bogu ,,jest", które uważa on za zróżnicowanie czystego istnienia w bytach kategorialnych ${ }^{54}$. Nie oznacza to jednak zasadniczej różnicy w pojmowaniu Boga u Gilsona czy Weltego. Obydwaj przyjmują, że jest On Czystym Istnieniem a każdy na swój sposób stara się uwyraźnić Jego całkowitą transcendencję i niewyrażalność. W odniesieniu do Weltego możemy natomiast sparafrazować słowa Gilsona, które wypowiada on pod adresem Heideggera, aby oddać dobrze to, o co chodzi. „Nie pozwala nam się powiedzieć, że byt „jest" - pisze Gilson - w obawie, byśmy raz jeszcze nie rozumieli ,jest” jako oznaczające „coś, co jest”..." 55 — Welte zaś nie chce

51 W rozprawie Die Gottesfrage im Denken Heideggers Welte pisze: „Das Sein ist das andere des Seienden. Denn ob dieses ist oder jenes ist, ja ob überhaupt etwas ist oder nichts ist, alle derartigen Möglichkeiten des Seienden sind vom Sein überwaltet und bestimmt, aber an keine von ihnen ist das Sein gebunden. Es erhebt sich weitraümig über alles Seiende und alle seine Möglichkeiten." - Dalej zaś stwierdza, że słowo „jest” wyraża „to, co jest” (das Seiende): „Davon spricht unsere Sprache, indem sie das Wort ,ist", mit dem sie alles Seiende aussagt, als eine Abwandlung des anderen und doch selben Wortes "sein" hervorbringt. Das, was die Sprache mit „sein” sagt, differenziert sich selbst zum „ist” des Seienden," s. 268.

52 Stanowi to odpowiedź na zarzuty Heideggera, (także Tillicha), a zarazem ukazanie właściwego sensu metafizyki sw. Tomasza.

53 Pojęcie Boga w filozofii św. Tomasza z Akwinu, ss. 211 i 209.

54 Por. jeszcze przypis 51 .

55 Byt i Bóg, s. 311. 
używać słowa ,jest” w odniesieniu do Boga, aby raz jeszcze nie uważano, że tak jak Średniowiecze a potem Descartes ujmujemy Boga jako jeden z bytów, które są, ale że docieramy w sferę nieskończoności, w sferę tego, co jest nie do wypowiedzenia, od której wszystkie byty otrzymują wyjaśnienie i sens swej egzystencji, krótko, że docieramy do tego, który $\mathrm{w}$ języku religii zowie się Bogiem żywym ${ }^{\mathbf{5 6}}$.

e) Rezultat dotychczasowych analiz fenomenologicznych.

Jak należy określić noezę, która się nam tutaj prezentuje? Czy skupioną i obejmującą siebie, milczącą i wypełnioną myśl tym, co jest nie do pomyślenia nie należy nazwać religijnością w pierwotnym sensie? $\mathrm{Na}$ to pytanie wypada nam odpowiedzieć twierdząco. Szczególnie mocno podkreśla tę postawę rozumu naturalnego także Maritain: „Postępowanie, dzięki któremu rozum dowodzi, że Bóg jest, nadaje samemu rozumowi postawę adoracji naturalnej i podziwu" ${ }^{57}$. - Także Jean-Hervé Nicolas wyraźnie stwierdza, że: ,poznanie Boga ma w swojej istocie charakter adoracji i wezwania, a jeżeli nie chce być wyraźnie takie, to wbrew swemu naturalnemu dążeniu. Lecz żadna adoracja, żadne wezwanie nie byłoby możliwe, gdyby nie było najpierw prawdziwego poznania Tego, do którego akty te się zwracają: poznania zawsze i koniecznie implikowanego w adoracji, które filozofia religijna musi uwyraźnić i którego nie może odrzucić bez zaprzeczenia samej siebie. Nie adoruje się, nie wzywa się Bytu nie wiedząc, że On jest godny adoracji". ${ }^{58}$

Jak zaś należy nazwać to szczególne noema w tej formie, w jakiej ono występuje? Ze względu na jego absolutną wyższość i absolutną rangę, ze względu na to, że jest ono całkowicie ponad bytem rzeczy, a zarazem obejmujące nas i całość istnienia naszego i świata, przychodzące do nas w milczeniu i nabożeństwie, musimy nazwać Świętym. Fenomenalna bowiem istotą Swiętego jako takiego w swych decydujących rysach polega na jedności wymienionych wyżej cech. - I tę Tajemnicę musimy nazwać także Misterium, albowiem przez nie rozumiemy pierwotnie to, co nas i wszystko obejmuje i dotyczy, i które równocześnie jest transcendentne. ${ }^{59}$

Myśl więc, która wychodząc od rzeczy jako istniejących zwraca się do ich transcendentnej podstawy, gdy bierze się pod uwagę pierwotny charakter jej drogi, dochodzi do sfery Świętego jako Świętego i we-

56 Filozoficzne poznanie Boga ..., s. 473.

57 Approches de Dieu, s. 21; równ. Les Degrés du Savoir, tamże, s. 446.

53 Afirmacja Boga a poznanie, w: Studia $z$ filozofii Boga, s. 281. - Na religijny moment charakterystyczny dla tego rodzaju noezy zwraca także uwagę Gilson: "Lęk wobec czystego istnienia - to być może tylko inna nazwa oznaczająca bojaźń bożą," Byt $i$ istota, s. 328. - Dalej zaś podkreślając, że wysiłek „aby myśleć o bycie” doprowadza nas do tego, co niewyrażalne, zwraca uwagę na element religijny i modlitewny u św. Tomasza, który się u niego z tym wiąże. Byt i istota, s. 329 .

59 Der Gottesbeweis ..., s. 329. 
wnętrznie do niej przynależy. Łączy się też z tym odpowiednia forma myśli.

$\mathrm{Za}$ Weltem wypada nam więc stwierdzić, że podstawowa myśl dowodów istnienia Boga prowadzi nas do fenomenalnych początków religii i ujmuje je myślowo.

f) Obecność momentu religijnego w filozoficznych określeniach Boga.

Duża część zarzutów przeciwko dowodom istnienia Boga - jak wiadomo - polega nie tylko na nieporozumieniu dotyczącym samego charakteru dowodzenia ${ }^{60}$, ale dotyczy także kategorii, które stanowią filozoficzne określenia Boga. Zarzuca się, że są to kategorie sprowadzające Go do rzędu tego, co jest, a więc nie gwarantujące pełnej transcendencji Boga ani też nie wyrażające Boga religii ${ }^{61 .}$

$\mathrm{Na}$ zarzut ten analizy Weltego, które staraliśmy się skonfrontować i w ten sposób poszerzyć, odpowiedziały tylko częściowo: dowodzenie, jeśli się uwzględni jego wymiar fenomenalny i punkt wyjścia, łącznie z zasadą, na której się opiera, prowadzi do Boga religii. - Czy jednak same określenia Boga jak Causa Prima, Ens Necessarium, itp., do których dochodzą poszczególne dowody, nie implikują wymiaru religijnego i są błędne - jak to sugeruje Heidegger, a po nim także Tillich względnie nieadekwatne - jak to utrzymuje m. in. Sciacca? ${ }^{62}$ Nie wydaje się, by tak było, przynajmniej w każdej filozofii. Zagadnienia tego nie sposób w ramach naszego artykułu rozwijać szczegółowo. Zwrócimy więc uwagę na główne momenty rozwiązania, które naszym zdaniem zawiera się $\mathrm{w}$ systemie metafizyki Tomaszowej.

1-o. Nie można ograniczać się do bezpośredniego, gramatycznego znaczenia terminów występujących w konkluzjach dowodów. Co one właściwie i w pełni oznaczają wiąże się z systemem metafizycznym, do którego przynależą. Dla każdego, kto dostatecznie zaznajomiony jest z filozofią św. Tomasza, jest rzeczą wiadomą, że tzw. Pierwszą Przyczyną, Bytem Koniecznym itp. może być tylko czyste Esse ${ }^{63}$, a więc rzeczywistość całkowicie transcendentna, przekraczająca wszystko, a nie byt czy jakakolwiek doskonałość podniesiona do najwyższego stopnia.

2-o. Bóg dowodzenia filozoficznego wyrażony jest wprawdzie w języku, którym mówimy o stworzeniach. Stąd - jak to już zaznaczyliśmy poprzednio - wymaga on zawsze poprawki. Jest to jednak konieczność,

60 Por. m. inn. Paul Tillich, Systematic Theology, The University of Chicago Press, 1951, t. I, ss. $204-205$; por. równ. Approches de Dieu, s. 21.

61 Por. przypis 17.

62 Por. M. F. Sciacca, L'existence de Dieu, Paris, 1951, s. 67, także, s. 60-61.

63 Por. dla przykładu Gilson, Tomizm, ss. 139 ns.; tenże: Pojęcie Boga w filozofii sw. Tomasza, szczególnie s. 214. - Tak ujęty Bóg odpowiada zaś jak najbardziej czystemu pojęciu Boga, które stanowi własność tradycji starotestamentowej i chrzescijańskiej. Zob. Geffré, Teologia naturalna $i$ Objawienie $w$ poznaniu Boga jedy- 
na którą jesteśmy skazani i z której na ogół wszyscy próbujący mówić - Bogu zdają sobie sprawę ${ }^{64}$.

3-o. Filozoficzne określenia Boga jakkolwiek ujmują Go przede wszystkim w kategoriach obiektywnej rzeczywistości, tak, że zdają się wyrażać zasadę natury (świata), to w pełnym swym znaczeniu — tak jak je rozumiał św. Tomasz i jego interpretatorzy - wyrażają również Boga, w którym rozwiązuje się sens egzystencji człowieka. Zwróciliśmy na to uwagę w artykule „Bóg filozofów a Bóg wierzących”: ,W czasach Tomasza poprzez rozwiązanie problemu natury człowiek rozwiązywał również problem swej własnej egzystencji. Czując się cząstką świata, mikrokosmosem, pytając się o ostateczną rację wszechświata, pytał się tym samym o źródła własnego bytu. Przeżywając wspólnotę własnego powstawania i śmierci z innymi bytami, które stanowią jego otoczenie, wysuwał hipotezę Bytu Koniecznego jako podstawy własnej egzystencji”. ${ }^{65}$

4-o. Na koniec warto jeszcze zauważyć, że tego rodzaju terminy właściwie rozumiane, a więc przy uwzględnieniu odpowiadającego im typu analogii, doprowadzają rozum do afirmacji Nieskończonej Tajemnicy. i wykluczają tym samym, by miał on być miara Boga ${ }^{66}$.

$\mathrm{Na}$ podstawie wszystkich przytoczonych wyżej racji wydaje się być uzasadnionym utrzymywanie, że Bóg dowodzenia filozoficznego jest Bogiem religii. Filozoficzna bowiem artykulacja Boga, jakkolwiek uwyraźnia Go w kategoriach ontologicznych, nie jest częściowym ujęciem Boga pomijającym właściwości Boga religii, ale je implikuje. Stąd różnica pomiędzy religijnym ujęciem Boga a ujęciem filozoficznym sprowadza się naszym zdaniem do tego, że w ujęciu religijnym najpierw wskazuje się na Boga kontaktu osobowego, który implikuje odpowiednią ontologię,

nego, ss. $254-255 ; 257-258 ; 260-261 ; 263$. - To samo stwierdza ks. Ignacy Różycki, Dogmatyka, ks. II, Kraków, 1948, ss. 229; 232 ns.; pod koniec analizy każdej z pięciu dróg do Boga zauważa on: „Wszystkie wymienione cechy, zawarte w pojęciu niezmiennego sprawcy zmian, wskazują wyłącznie na Boga chrześcijańskiej religii"; „,przymioty te (pierwszej przyczyny) przysługiwać moga tylko prawdziwemu Bogu religii chrześcijańskiej", s. 232, podobnie na innych miejscach.

64 „Już św. Tomasz wykazywał, że wszystkiemu, co się o Nim mówi, winno się zarazem zaprzeczać, że teologia negatywna jest niezbędnym uzupełnieniem teologii afirmatywnej. I na tym właśnie polega nauka o analogii, która pozwala nam wprawdzie mówić o Bogu, słowami odnoszącymi się do świata stworzonego, ale pod tym ściśle sprecyzowanym warunkiem, że są one w innym znaczeniu prawdziwe, gdy idzie o Boga, a w innym gdy idzie o stworzenie," J. Daniélou, Bóg $i m y$, ss. $41-42$; por. równ. przypis 49.

65 Bóg filozofów a Bóg wierzacych, ss. 100-103.

66 ,... jakże wspaniały jest nieustraszany wysiłek intelektu, który przy calym szacunku dla tajemnicy nie wyrzeka się chęci rozumienia, posuwa się aż po krańce swoich możliwości i zatrzymuje się dopiero tam, gdzie zmógł go zbyt wielki blask oślepiającego światła. Owa nieustraszoność intelektu w badaniu tajemnicy stanowi - niezniszczalnej wielkości św. Tomasza z Akwinu," J. Daniélou, Bóg $i$ my, ss. 37-38; tamże, s. 42. Por. równ. Tomizm, s. 512, gdzie Gilson zauważa, że metafizyk nie może zrezygnować ani z problemu ani z tajemnicy i że, istnieje pewna tajemnica, która stanowiąc podstawę metafizyki, jest przedmiotem filozofii par excellence. Jest to tajemnica aktu istnienia." 
zaś w ujęciu filozoficznym najpierw wskazuje się na właściwości ontyczne, które implikują cechy Boga religii ${ }^{67}$.

\section{CHARAKTER DOWODOWY PROCESU MYŚLI DOCHODZĄCEJ DO BOGA}

a). Moment dowodzący w procesie myśli.

Przedstawione wyżej analizy dotyczyły fenomenalnego charakteru duchowego procesu, który doprowadza myśl do Boga. Powstaje jednak pytanie, $\mathrm{w}$ jakim stopniu $\mathrm{w}$ tego rodzaju procesie dowodzimy rzeczywistości Nieskończonej i Świętej Tajemnicy? Gdzie znajduje się właściwy moment dowodzący w demonstratio Deum esse? Welte - jak sam wyraźnie zaznacza - nie chce rozwijać teorii dowodów istnienia Boga. Chce ująć tylko decydujący moment dowodzenia od jego strony fenomenalnej.

Zdaniem Weltego, kiedy duch zostaje uwrażliwiony na istnienie tego, co jest i dokonuje procesu, o którym była mowa wyżej, to staje się dla niego widoczne, że byt tego, co jest, rozpatrywany sam w sobie, a zatem bez uwzględnienia aliud jego transcendencji, nie jest zdeklarowanie bytem i o tyle jest nicością. Jest to szczególnie wyraźne tam, gdzie byt rzeczy w swym transcendentnym napięciu przybiera charakter problematyczny ${ }^{68}$.

Przeciwko tego rodzaju nie całkiem zdecydowanej nicości podnosi równocześnie byt rzeczy sprzeciw: jest przecież, co jest. Przybiera ono nawet wyraźnie moc. Jest, co jest.

W tym właśnie sprzeciwie i w tym ponownym odnalezieniu bytu leży - zdaniem Weltego - ergo dowodzenia. Jeśli byt rzeczy sam w sobie nie jest całkowicie zdeklarowaną nicością, a równocześnie jest po prostu zdeklarowany, to jest zrozumiałe, że zdeklarowana bytowość nie leży w samej rzeczy, że więc dochodzi do niej ab alio: omnis res cuius esse est aliud quam sua natura habet esse ab alio.

Jest rzeczą oczywistą, że to, co ustanawia byt rzeczy, nie jest samo żadną z tych rzeczy. Zdecydowana bowiem bytowość rzeczy wskazuje na coś różnego od niej, na absolutne, nieskończone i niepojęte $M i$ sterium. Znaczy to, że w zdeklarowanej bytowości tego, co jest, a zatem w jego rzeczywistości, jest dana rzeczywistość nieskończonego i świętego Misterium jako jedyna moc, która ustanawia wszelki byt. Kiedy rodzi się więc zasadnicze pytanie i zdziwienie jedno nie może być potwierdzone bez drugiego. Swięte, którego żadne słowo nie nazywa i żadna

67 Por. w tym względzie: John Courtney Murray, Le problème de Dieu, (tłum. z ang.), Paris, 1965, szczególnie ss. 58 ns.

${ }_{68}$ Der Gottesbeweis ..., ss. 330-331. 
myśl nie pojmuje, jest rzeczywistością, albowiem jest rzeczywistością, że jest, co jest.69.

To samo - na swój sposób utrzymuje Maritain. Intuicja bytu „,zmieszanego" z nicością odsyła nas bezpośrednio do Bytu wolnego od wszelkiej nicości, absolutnego i niezniszczalnego. Owocem tej intuicji jest spontaniczne rozumowanie. Widzę, że byt mój podlega śmierci i że zależy on od świata, którego jestem częścią. Równocześnie dostrzegam, że byt „zmieszany” z nicością, aby był, implikuje byt bez nicości. Nie jest nim świat, którego jestem częścią. Jest on bowiem, jak mój byt, bytem ,zmieszanym z nicością i nie istniejącym przez siebie. Stąd, dostrzegam, że poza nim istnieje Byt bez nicości. Istnieje całkiem inny Byt, transcendentny, wystarczający sobie i niepoznany $w$ sobie. Byt per se. ${ }^{70}$

Przyjęcie tej podstawy dowodzenia istnienia Boga i jej uwyraźnienie ma szczególne znaczenie, gdy chodzi o właściwą interpretację charakteru dowodowego dróg do Boga. Zwróciliśmy na to uwagę już poprzednio poruszając problem, $w$ jaki sposób ma zastosowanie racja bytu $w$ naszym dowodzeniu istnienia Boga. ${ }^{71}$ Nie ulega bowiem wątpliwości, że ma ona tutaj miejsce $i$ warunkuje przez to swoisty proces dowodzenia istnienia Boga. Odczytujemy ją właśnie jako bezwzlędnie ważne prawo rzeczywistości bytu, który stanowi przedmiot naszego doświadczenia i naszej intuicji. W sposób niezreflektowany doświadczamy radykalnej przygodności bytu (intuicja bytu ,zmieszanego z nicością, doświadczenie bytu, który nie jest przez siebie zdeklarowanym bytem), która przez to wskazuje na inny Byt - Absolut jako swoją rację. Maritain mówi tutaj o racjonalnej wartości bytu, która pozwala dostrzec Istnienie Absolutne, albo Byt bez nicości, całkowicie transcendentny. W oparciu o nią stajemy $w$ obliczu istnienia Boga. ${ }^{72}$ - Tego rodzaju zaś charakter radykalnej przygodności bytu, który ukazuje istnienie Bytu Absolutnego jako racji swojego istnienia, „dowodzimy” w bycie poddanym zmianie, pozostającym $\mathrm{w}$ związkach przyczynowych czy poddanemu powstawaniu i niszczeniu... ${ }^{73}$

b) Dowodzenie istnienia Boga a Jego afirmacja.

W konsekwencji dostrzeżenia tego rodzaju charakteru bytu, który odsyła poza siebie, ukazuje się dla umysłu ludzkiego rzeczywistość Nie-

69 J. W., s. 331

70 Approches de Dieu, ss. 13-15.

71 Przedfilozoficzne $i$ filozoficzne poznanie Boga, ss. 343-345.

72 ,Ainsi le dynamisme interne de l'intuition de l'existence, ou de la valeus: intelligible de l'être, me fait voir que l'Existence absolue ou l'Etre-sans-néant transcende la nature entière; et me voilà en face de l'existence de Dieu," Approches de Dieu, ss. $14-15$.

73 Por. Przedfilozoficzne $i$ filozoficzne poznanie Boga, s. 346. 
skończonej i Świętej Tajemnicy. Tego rodzaju jednak wykazanie Jej rzeczywistości, jakkolwiek ma tutaj miejsce właściwe wykazanie ${ }^{74}$ nie jest zmuszające zewnętrznie ludzkiego ducha. Nie opiera się ono bowiem na oczywistości przyporządkowanych ludzkiemu duchowi przedmiotów właściwych, jakimi są dla niego istoty rzeczy materialnych. Welte cytuje św. Tomasza, który w De Veritate (14.1) stwierdza: intellectus possibilis movetur ... a proprio objecto, quod est forma intelligibilis, scilicet quod quid est".

W naszym jednak przypadku horyzont bytu kategorialnego „tego, co jest" zanika.

Mimo to, ta wielka Tajemnica ukazuje się dla umysłu jednoznacznie i wyraźnie, kiedy ten w autentycznie transcendentującym ruchu i wyraźnie rozwiniętym dowodzeniu zwraca się ku niej. Uzasadnia ona ",tak" ludzkiego umyslu, jakkolwiek nie dzieje się to tak jak w przypadku bytów kategorialnych. Ze swej wyżyny odwołuje się Ona do tego, co jest najwyższe we mnie, do wolnego samoposiadania mojego ducha. Udowodnienie, które prowadzi do „tak”, i które go uzasadnia, odwołuje się do „tak" mojej wolności. Możemy dlatego powiedzieć, że proces dowodzenia tutaj posiada formę uzasadnienia, która nie narusza w nim charakteru osobistego apelu. To, co się ukazuje, w tym dowodzeniu winienem potwierdzić. Dotyczy to jednak bezpośrednio mnie, i muszę to sam, w sposób wolny dokonać. ${ }^{75}$

Wydaje się, że warto zwrócić uwagę na cytowany przez Weltego w przypisie tekst św. Tomasza z De Veritate (14.1), który w sposób mistrzowski wyjaśnia, jak to jest możliwe, że tego rodzaju dowodzenie nie tylko nie narusza, ale postuluje osobową decyzję. Ponieważ intelekt nie stoi tutaj w obliczu swego przedmiotu właściwego, stąd jego zaktualizowanie wymaga poruszenia woli: intellectus possibilis non movetur nisi a duobus, scilicet a proprio obiecto, ... et a voluntate, quae movet omnes alias vires.

$\mathrm{Na}$ tego rodzaju egzystencjalny moment w afirmacji Boga zwraca szczególną uwagę również J. Daniélou, wychodząc z właściwości tzw. zagadnień granicznych (progi rozumu), wśród których należy umieścić także Boga. Zagadnienia graniczne tym się charakteryzują, że nie dadzą się zawrzeć w definicji (Bóg wymyka się definicji), oraz tym, że żądają postawy całościowej, nawrócenia się egzystencjalnego. Dzieje się tak dlatego, że zagadnienia graniczne angażują egzystencję osoby. „W stopniu najwyższym odnosi się to do Boga. Bóg jest w całym znaczeniu tego słowa

74 W jakim sensie można tutaj mówić o „dowodzeniu" czy wykazaniu, por. jeszcze Maritain, Approches de Dieu, ss. 19-21; równ. nasz artykuł: Przedfilozoficzne i filizoficzne poznanie Boga, ss. 343-344; 346.

75 Der Gottesbeweis ..., s. 333. 
tym, kim nie mogą rozporządzać. Wobec Niego mój akt poznania pojawia się jako akt egzystencjalny, akt kogoś kto istnieje". ${ }^{76}$

Co oznacza to od strony fenomenalnej? Otóż poruszamy się $\mathrm{w}$ duchowej przestrzeni skupienia, milczenia i uwieỉbienia, w obliczu rzeczywistości mającej rozstrzygające znaczenie dla wszelkiego bytu. Rzeczywistość ta jest dla ducha Nieskończoną i Świętą mocą. W jej afirmacji zostaje potwierdzone wszystko co jest, zaś w jej zagubieniu wszystko zanurza się $\mathrm{w}$ bezmiarze problematyczności. Dotyczy ona mnie i wszystkiego. Ukazująca się $\mathrm{w}$ ten sposób rzeczywistość tego, co Najwyższe podnosi mnie samego na wyżyny przez skierowany do mnie apel, który dosięga mnie najgłębiej i w całości. - Bardziej niż milczenie, potwierdzeniem tej Nieskończonej i Świętej Mocy jest uwielbienie, które dopełniam w skupieniu i ciszy.

Tego rodzaju noezę, ten akt ducha nacechowany uwielbieniem i skupieniem możemy nazwać - zdaniem Weltego - wiarą w religijnym sensie. Wiara ta ma wspólne z tym, co nazywamy wiedzą, że podstawa jej jest dowodzona. W sposobie jednak uzasadnienia, przede wszystkim zaś w sposobie rzeczywistego, pierwotnego $\mathrm{i}$ istotowo prawidłowego jej dokonania różni się ona od formy wiedzy, tak jak jest ona możliwa wewnątrz kategorii świata.

Tego rodzaju Noumenon, który w ten sposób mnie dotyczy i we wnętrzu ogarnia, określa i woła, będzie posiadał w tym osobistym apelu fenomenalny charakter osobowego "Ty".77 Jest on równocześnie całkowicie niewypowiedziany. Tym samym fenomenalnie jest tutaj początek i zarys tego abyśmy mogli mówić o Bogu jako Bogu, dokładnie o Bogu jako o Bogu moim. ${ }^{78}$

\section{PODSUMOWANIE ANALIZ}

Do jakich ustaleń prowadzą nas podjęte wyżej rozważania na temat stosunku dowodów istnienia Boga do fenomenu religii? Postaramy się je ująć kolejno w następujących punktach:

1. „Dowody” istnienia Boga, gdy uwzględnimy nie tylko ich postać zewnętrzną, ale podstawową myśl, która się w nich zawiera, stanowią filozoficzną artykulację pierwotnego, religijnego dochodzenia człowieka do Boga. Proces ten posiada charakter religijny zarówno ze względu na jego formę dokonywania się, jak i ze względu na swój przedmiot.

76 J. Daniélou, Bóg i my, ss. 42-43.

$77 \mathrm{Na}$ temat osobowego charakteru Boga i jego poznania por. równ. J. Daniélou, Bóg i my, ss. 50-54.

78 Der Gottesbeweis ..., s. 334. 
Tym samym - nawiązując do analiz B. Weltego - staraliśmy się pokazać od strony dowodów istnienia Boga to, na co nieraz zwracaliśmy uwagę przy analizie religijnego poznania Boga, że nie ma zasadniczej antynomii pomiędzy Bogiem religii a Bogiem filozofii. Dowodzenie istnienia Boga dosięga Boga religii - przy pomocy właściwych sobie środków refleksji. Nie oznacza to - podkreślmy raz jeszcze - pomieszania obu porządków: religijnego i filozoficznego.

2. Potwierdzeniem tego, że dowodzenie istnienia Boga stanowi filozoficzną artykulację duchowego procesu o charakterze religijnym i że dosięga Boga religii jest także to, że filozoficzne określenia Boga, będąc owocem każdej z poszczególnych „dróg”, jeśli uwzględnimy ich pełne, wewnątrz-systemowe znaczenie - bez odwoływania się do jakichkolwiek interpretacji z zewnątrz - wskazuje również na Boga religii. Przejście więc od Boga wyrażonego w języku filozofów do Boga religii uwarunkowane jest logiką wewnętrzną odpowiedniego systemu, która ukazuje w samym przedmiocie dowodzenia momenty religijne, a nie zasadza się przede wszystkim na jedności podmiotu, w którym spotykają się filozof i wierzący. Nie jest to oczywiście przekreśleniem zależności czy wpływu historyczno-psychologicznego religii na myśl filozoficzną, ani też odwrotnie, wpływu filozofii na odpowiednie rozumienie czy tłumaczenie treści religijnej. - Musimy jednak wyraźnie odgraniczyć jak to już zaznaczyliśmy - dziedzinę zależności faktycznej, historycznej i psychologicznej, od tego, co stanowi strukture samego duchowego: procesu, czy nawet całego systemu filozoficznego wraz z tym co niesie on ze sobą.

3. Analiza tego duchowego procesu ukazuje nam ponadto, w jaki" sposób dosięga on rzeczywistości boskiego „Ty”, dzięki czemu posiada on znaczenie nie tylko $\mathrm{w}$ porządku istotowym ale rzeczywistym, decydującym dla dziedziny religii. - Metafizyczna artykulacja tego duchowego procesu, którego św. Tomasz dokonał w sposób mistrzowski, posiada właśnie ten sens, aby uwyraźnić metafizyczne znaczenie rzeczywistości podstaw religii w ramach historycznie nowej i bardzo rozwiniętej teoretycznej świadomości ${ }^{79}$.

Podobnie jak w poprzednich naszych publikacjach, zamierzeniem naszym w niniejszym artykule było wskazanie na kierunek rozwiązania poruszonej problematyki, nie zaś wyczerpujące jej przedstawienie w szczegółach. Staraliśmy się przy tym uczynić to w formie dialogu $\mathrm{w}$ tej mierze, $\mathrm{w}$ jakiej na to pozwalają ramy artykułu - z przedstawicielami innych kierunków filozoficzno-teologicznych, a mianowicie fenomenologią egzystencjalną reprezentowaną przez Heideggera (a w te-

79 J. W., S. 335. 
ologii przez Tillicha). Uwzględnienie pewnych postulatów, które wiążą się z wyostrzonym zrozumieniem specyficzności różnych dziedzin rzeczy, nie musi prowadzić do synkretyzmu ani też do rezygnacji z niewątpliwych historycznych osiągnięć myśli filozoficznej. Przeciwnie, pozwala na jej swoistą reinterpretację, która wydaje się być nie tylko bardziej zgodna $\mathrm{z}$ autentyczną myślą jej twórców ale wyzwala ją także od racjonalistycznej interpretacji, której niewątpliwie w pewnych okresach historycznych podlegała, i w którym to kontekście jeszcze do dziś jest nierzadko odczytywana.

\section{Z U S A M M E N F A S S U N G}

\section{DIE GOTTESBEWEISE UND DIE RELIGION}

In diesem Artikel - anschliessend an seine frühere Publikationem - bestrebt der Verfasser eine Antwort auf die Frage zu finden, wie das Verhältnis der Gottesbeweise zu der Religionserkenntnis ist, insbesondere: führen die Gottesbeweise zm Gott der Religion oder nur zum Gott der Philosophen und Gelehrten?

Der Ausgungspunkt für seine Erwägungen ist haptsächlich ein Artikel von B. Welte: „Der Gottesbeweis und die Phänomenologie der Religion”, enthalten in: „Auf der Spur des Ewigen". Seine Ansichten konfrontiert er mit dene von E. Gilson, M. Heidegger, P. Tillich und J. Maritain. Alle diese Denker nehmen Stellung zu den Aspekten dieses Problems.

Das Auseinandersetzen zwischen den Genannten wird für die völlige Klärung und Lösung des Problems besonders nützlich sein. Charakteristich ist, dass Welte, ausgehend von Husserls Ansicht, der die philosophische Klärung aller Wissenschaften verlangt, der Meinung ist, dass Gottesbeweise - sollen sie ihre eigene Rolle erfüllen - auf ihre Art den von Natur aus religiösen urspünglichen Gedankengang ausdrücken und dadurch zu Gott führen müssen. In dieser Hinsicht ist er grundverschieden von Max Scheler, der das Konformitätssystem zwischen Religion und Philosophie vertritt.

Gilson, der wie Welte die Ursprünglichkeit des religiösen Gebietes annimmt und die Aufgabe des Philosophen im Durchdenken und Formulieren dieses Gebietes mit Hilfe philosophischer Begriffe sieht, verneint, dass die philosophischen Gottesbeweise im Bereich des religiösen Phänomens liegen.

Nach Ansicht des Verfassers liegt die Lösung des Problems darin, wie sich das Verhältnis zwischen der Erkenntnis Gottes aus eigenem Antrieb und einer prägnant betrachtender Erkenntnis gestaltet. Wenn daraus folgend die Gottesbeweise wie u. and. J. Maritain behauptet - eine Entwicklung und Erklärung der natürlichen Erkenntnis auf wissenschaftlichem Niveau sind, scheinen sie zum Gott der Religion zu führen. Zu diesem Zweck unterzieht der Verfasser nach Welte den Grundgedanken einer Analyse, die der Ausgangspunkt und Grundsatz für die fünf Wege des hl. Thomas ist und zwar: „oportet, quod sit aliqua res, quae sit causa essendi omnibus rebus eo, quod ipsa est esse tantum; alias iretur in infinitum in causis, cum omnis res, quae non est esse tantum, habet causam sui esse" (De ente et essentia, 5). 
Die Beschreibung dieses Gedankenganges, der sich zwischen zwei Termini bewegt: res quae non est esse tantum und esse tantum, lässt den spezifischen Charakter des Gedankens und des Gegenstandes der Erkenntnis hervorheben. Der Gedanke, der die Sache als existierende aufnimmt, ist verschieden von der abstrakten und objektiven Gedankenform. Er nimmt die Gestalt der Einheit und Sammlung an. Gleichzeitig entstehen in ihm Verwunderung und Fragen. Er nimmt wahr, dass im Sein des Seienden die Beziehung zum unendlichen Geheimnis enthalten ist. Dieses unendliche Geheimnis ist das - was auch Maritain hervorhebt - was uns unsere Ideen und Belege, unendlich überragt.

Das unendliche Geheimnis ist nicht nur Mass und Grund des Seienden, bestimmt aber auch unser ganzes geistige Leben. Welte sagt, dass ,vor dieser unendlichen Transzendenz das Denken in seiner begreifenden und aussagenden Form am Ende ist". Denn ipsum esse ist in keiner Kategorie anthalten: non est in aliquo genere. Obwohl die Terminologie Weltes verschieden von der Terminologie Gilsons oder Maritains ist, heben sie doch alle die Transzendenz des ipsum esse hervor. Das entsprechende Denken hat schon selbst religiösen Charakter. Auf verschiedene Art betonen das Welte, Maritain, J. H. Nicolas und auch Gilson. Das auf diesen Wege Erscheinende kann man Heilig oder Mysterium nennen; es besitzt nämlich alle Züge, die diesen Begriffen zu eigen sind.

Der Verfasser des Artikels bemerkt noch, dass in den philosophischen Bezeichnungen, ein religiöser Moment vorhanden ist. Diese Bezeichnungen, in ein entsprechendes System eingereiht, sind volle Auffassung von Gott, sie schalten ihn nicht gleich mit den Geschöpfen, doch implizieren sie die Eigenschften des Gottes der Religion. Aus diesem Grunde bezeichnet der hl. Thomas den Terminus ad quem der Beweise als Gott.

Im Gedankengang, der zur Erkenntnis Gottes führt, befindet sich auch ein Zeugnis für seine Existenz. Dass ergo dieses Zeugnisses beruht darauf, dass die Entschiedenheit des Seins nicht im Seienden liegt und ihm gleichwohl zukommt, dass sie ihm also ab alio zukommt. Omnis res cuius esse est aliud quam sua natura habet esse ab alio. In Wirklichkeit des Seiendes ist uns die Wirklichkeit des Unendlichen und des Heiligen Mysteriums gegeben. Der Verfasser des Artikels betont, dass dieses ein Ablesen des Daseinsgrundes ist (dieses was ist). Obwohl die Erweisung für die Existenz von Gott eine eigentliche Erweisung ist, zwingt sie den menschlichen Geist von aussen nicht, sie hat die Eingenschaft eines Appells, denn was sie zeigt, stützt sich nicht auf die Überblickbarkeit der Gegenstände, die dem menschlichen Geiste zustehen. Folglich kann sich die Affirmation der Gottesexistenz nur durch den persönlichen Willensakt vollziehen. Die volle Affirmation bedeutet hier Anbetung in Sammlung und Stille. Darum kann mann diesen Akt auch als Glaube im religiösen Sinne bezeichnen. Mit der Wissenschaft hat er gemeinsam, dass seine Gründe erwiesen sein können. Doch die Art seines Vollzuges ist verschieden von der Art der Wissenschaften. Das Noumen, welches durch den an das Innere des Menschen gerichteten Appell diesen umfängt und bestimmt, hat also einen persönlichen Charakter des „Du”. Von hier stammt der in Umrissen angedeutete Anfang dessen, was wir mit „Deus meus” bezeichnen. 